\title{
EXPERIMENTAL INVESTIGATION OF NEW ADDITIVE TO OPTIMIZE THE PROPERTIES OF SYNTHETIC-BASED DRILLING FLUID
}

\author{
Ali Akbar Daya ${ }^{\#}$, Majid Sajjadian, Ehsan Esmaeilpour Motlagh \\ University of Sistan and Baluchestan, Department of Mining Engineering, Zahedan, Iran
}

(Received: October 5, 2015; Accepted: November 8, 2016)

\begin{abstract}
This paper focus on the design, development and testing two type of synthetic based drilling fluid include of amine-treated Quebracho agent and Polymeric Fluid Loss agent. Amine-treated Quebracho agent is compatible with other chemical additives in Synthetic-Based Fluids and it shows high-temperature stability, low fluid losses and good Rheological properties. Traditionally invert emulsion drilling fluids have been used to optimize drilling performance primarily due to the high level of wellbore stability and high penetration rates shown while using these fluids. Invert emulsion fluids require various additives such as emulsifiers, fluid-los-control (FLC) agents, viscosifier etc. The paper includes the laboratory evaluation for high temperature application of two agents in invert emulsion drilling fluids.
\end{abstract}

Key words: Synthetic-Based Drilling Fluid, rheological properties, Temperature Stability.

\section{Introduction}

Oil drilling has encountered increasingly challenging scenarios due to the difficulty of finding large oil reserves; moreover, the operational window associated with these scenarios has become increasingly narrow. Thus, to provide continuity of oil exploration in Iran, it is necessary to critically analyze the processes involved and search for ways to optimize them [1]. During the drilling process, a fluid is used to remove the cuttings generated by the bit from the well. With the evolution of the drilling process, several types of drilling fluids emerged. The classification of a drilling fluid is most commonly made on the basis of its composition [2]. These fluids are classified into water-based fluids (WBFs) and non-aqueous fluids (NAFs). NAFs are classified as synthetic or oil-based fluids. Synthetic drilling fluids are chemical formulations, while oil-based fluids are petroleum derivatives [3]. More costly oilbased muds were used which were usually more stable than the water-based mud (when drilling a deep well at high temperatures) [4]. Oil-based mud was more advantageous to use when drilling into subterranean formations which contain water swell able clays in as much as being damaged by water contact. Because of their comparatively lower cost and good availability, crude oil petroleum and diesel oil had been used in the formation of oil-based mud [5]. All such petroleum-based oils used for drilling mud contain relatively large amounts of aromatics and at least a substantial concentration of n-olefins both of which may be harmful or toxic to animal and plant life. The drilling industry had developed several types of synthetic-based muds (SBMs) that combine the desirable operating qualities of the oil-based mud, lower the toxicity and environmental impact qualities of the waterbased mud. It could also, improve the drilling

\#Corresponding author: aliakbardaya@eng.usb.ac.ir 
efficiency without polluting the subsurface structures. Synthetic-based fluids are drilling fluids whose base fluid consisted of non-water soluble organic compounds and where neither the base fluid nor the additives were of petroleum origin. Thus, they are environmentally friendly, have high biodegradability and have lower toxicity. Synthetic based fluids were classified into four general categories: synthetic hydrocarbons, ethers, esters and acetals. Ester-based drilling fluids had been recognized for providing the best environmental performance of any synthetic based fluids and also they are fully biodegradable fluids. The rheological properties, the thermal stability and the filtration of the synthetic based mud were the most frequently used methods for selecting the best synthetic ester based mud [6,7].

In oil well drilling operations, two types of drilling fluids are generally utilized, waterbased drilling and invert emulsion drilling fluids. The most commonly used additive to viscosity an oil based drilling fluid is organophilic clay. The use of organophilic clay in the drilling fluid, however, has some disadvantages. The utility of organophilic clay to viscosity the low aromatic, high paraffin oil muds which are considered safer to marine life than the traditional diesel oil-based fluids is limited. In the absence of heat and/or high shear mixing, excess organophilic clay is needed to provide viscosity to the mud prior to its equilibration in the drilling system. Also, the quaternary ammonium salts from which the clays are prepared are generally thought to be toxic to aquatic organisms [8].

Oil based mud systems have long been the fluids of choice for many operators. These systems have been consistently proven as technically superior to conventional water based muds in the areas of borehole stability, ionic inhibition, rate of penetration, cuttings condition and sticking avoidance. Principally, the beneficial technical attributes are derived from the continuous organic phase and with the benefits being inherent in the base fluid, these muds are often considered easier to maintain and more tolerant to contaminants such as drill solids.

Baroid and Baker Hughes provided the most detailed recommended specifications for synthetic-base drilling muds. Tables 1 and 2 contain those mud property specifications for their SBM systems being utilized in Gulf of Mexico deep water drilling operations. The gel strengths listed in Table 2 are for 10 seconds, 10 minutes and 30 minutes, respectively [9].

Table 1. Synthetic-base Mud Specifications Recommended by Baker Hughes

\begin{tabular}{|c|c|c|c|}
\hline Mud Weight, lbs./gal. & Plastic Viscosity,cp & Yield Point, $1 \mathrm{~b} / 100$ sq. $\mathrm{ft}$. & Emulsion Stability, Volts \\
\hline 10.5 to 10.9 & 35 o 45 & 15 to 20 & $>400$ \\
\hline 10.9 to 14.1 & 45 to 55 & 12 to 18 & $>400$ \\
\hline 14.1 to 15.1 & 50 to 60 & 10 to 15 & $>500$ \\
\hline 15.1 to 15.2 & 50 to 60 & 10 to 15 & $>500$ \\
\hline 15.2 to 15.5 & 50 to 60 & 10 to 15 & $>500$ \\
\hline
\end{tabular}

Table 2. Synthetic-base Mud Specifications Recommended by Baroid

\begin{tabular}{|c|c|c|c|c|}
\hline $\begin{array}{c}\text { MudWeight, } \\
\text { bs./gal. }\end{array}$ & Plastic Viscosity,cp & $\begin{array}{c}\text { Yield Point,lb/100 } \\
\text { sq. } \mathrm{ft}\end{array}$ & $\begin{array}{c}\text { Gel Strength, lb/100 } \\
\text { sq. } \mathrm{ft}\end{array}$ & HTHP Fluid Loss \\
\hline 10.5 to 10.9 & 35 o 45 & 15 to 20 & $8,15,18$ & $<4 \mathrm{cc} / 30 \mathrm{~min}$ \\
\hline 10.9 to 14.1 & 45 to 55 & 12 to 18 & $12,18,20$ & $<4 \mathrm{cc} / 30 \mathrm{~min}$ \\
\hline 14.1 to 15.1 & 50 to 60 & 10 to 15 & $15,22,25$ & $<3 \mathrm{cc} / 30 \mathrm{~min}$ \\
\hline 15.1 to 15.2 & 50 to 60 & 10 to 15 & $18,25,28$ & $<3 \mathrm{cc} / 30 \mathrm{~min}$ \\
\hline 15.2 to 15.5 & 50 to 60 & 10 to 15 & $20,28,31$ & $<3 \mathrm{cc} / 30 \mathrm{~min}$ \\
\hline
\end{tabular}




\section{Material and experimental techniques}

\subsection{Test Methods}

Standard methods as outlined in API RP RB 13B-2 were used to test laboratory test fluids and evaluate their conventional drilling fluid properties such as plastic viscosity (PV), yield point (YP), 10-minutes and 10 seconds el strengths, electrical stability (ES), and hightemperature, high-pressure fluid loss (HTHP FL.). All samples were prepared according to the American Petroleum Institute [10]. All additives for ester based mud were obtained from the Baroid Company.

\subsection{Drilling Fluid Materials}

The concentration of each mud constituent was based initially on the M.I. specifications and communication with M.I. drilling fluids personnel, especially Fred Growcock. Over 40 tests were run on diesel oil-base and synthetic-base muds to arrive at the formulations reported below.

The primary difficulty in determining an appropriate formulation resulted from our goal of having the relative proportions of materials in the fluid phase of the mud. The drilling fluids were formulated using the following methods. The basis for synthetic base fluid required to formulate a given density mud is determined with equation 1 .

Base fluid $[\mathrm{ml} / \mathrm{lab} \mathrm{bbl}]=350[(-0.0285 \times$ Mud Weight) + 0.9652]

The equation gives the amount in milliliters of synthetic base fluid per lab barrel of mud given the desired mud weight expressed in ppg. Equation 1 is for mixtures with a synthetic base fluid to water ratio of 80:20 and was derived from a graph of data found in information provided by M.I. The base fluid for the drilling mud used in this research is a manufactured or "synthesized" hydrocarbon fluid named IO 1618. This fluid is an internal olefin that is a combination of $\mathrm{C}_{16} \mathrm{H}_{32}$ and $\mathrm{C}_{18} \mathrm{H}_{36}$. It is manufactured from pure ethylene. A synthetic base fluid to water ratio, SWR, of 80:20 was selected between the high ratios desired for a heavily weighted mud and low ratios used for unweighted muds. Therefore, the volume of brine in each density mud was determined so that the volume of water used to formulate the brine would be approximately $20 \%$, by volume, of the mixture of synthetic base fluid and water in the drilling fluid. For the $7.8 \mathrm{ppg}$ calcium chloride brine used in this study, the volume of brine was equal to the volume of water necessary to satisfy the 80:20 SWR divided by 0.922 . The $10.25 \mathrm{ppg}$ brine is a $25 \%$, by weight, solution of calcium chloride in water. This concentration of calcium chloride was selected based on recommendations in the M.I. reference material.

A wetting agent was added primarily to increase the suspension of the solids to be wet by the synthetic base fluid. The wetting agent concentration was also determined from the results of previous experiments. An emulsifier was added to keep the water-in-oil emulsion stable and to keep solids oil-wet. A low shear rate viscosifier was included to raise the low shear rate viscosity to improve cuttings and barite suspension properties. This liquid must be added with specific amounts of lime. Therefore, lime was added to ensure that both the low shear rate viscosifier and the emulsifier performed as intended.

Even though the cost of Gilsonite has increased recently, it is still one $f$ the most economical Fluid Loss Control additives for invert emulsion drilling fluids. Also, Gilsonite is a very versatile FLC additive for different temperatures due to its versatility and relatively low cost, there is the issue of potential formation damage which has made various papers to be written concerning formation damage and formation damage mechanisms while utilizing Gilsonite. 
However, formation damage by Gilsonite depends upon the type of formation drilled, fluid formulation and quality of Gilsonite. Gilsonite also has other performance-related issues-once the Gilsonite melts or dissolves, it contributes to high viscosity and gel strengths in the drilling fluid without contributing to fluid loss properties. The biggest drawback of Gilsonite is environmental concerns.

To overcome some of the aforementioned problems, such as environmental concerns, performance limitations, economic disadvantages and formation damage issues, a new amine-treated quebracho (ATQ) has been developed. This ATQ is completely soluble to dispersible in most based fluids. This product is stable to temperatures $\mathrm{n}$ excess of $400^{\circ} \mathrm{F}$ and performs well in a variety of drilling fluid formulations. The product is prepared from readily available naturally occurring quebracho and naturally occurring fatty acid derived fatty amine. ATQ is relatively nontoxic to marine environment and is HSE friendly. The performance of ATQ with respect to its fluid-loss control properties and formation damage is better than the traditional additives including Gilsonite. For two mud formulations, all chemical additives were added slowly using stirring and mixed well in the mixer. The components and concentrations used to formulate these fluids are given in Table 3 .

Table 3. Formulation Drilling Fluids

\begin{tabular}{|c|c|c|}
\hline \multirow{2}{*}{ Component } & \multicolumn{2}{|c|}{ Concentration } \\
\cline { 2 - 3 } & Polymeric Type & ATQ Type \\
\hline Polymeric Agent & $0.483 \mathrm{bpb}$ & $-\mathrm{bpb}$ \\
\hline Water & $0.126 \mathrm{bpb}$ & $0.126 \mathrm{bpb}$ \\
\hline Lime & $3.6 \mathrm{ppb}$ & $3.6 \mathrm{ppb}$ \\
\hline $\mathrm{CaCl}_{2}$ & $14.74 \mathrm{ppb}$ & $14.74 \mathrm{ppb}$ \\
\hline Organophilic Clay & $4.0 \mathrm{ppb}$ & $4.0 \mathrm{ppb}$ \\
\hline Emulsifier & $5.0 \mathrm{ppb}$ & $3.0 \mathrm{ppb}$ \\
\hline Wetting agent & $5.3 \mathrm{ppb}$ & $5.3 \mathrm{ppb}$ \\
\hline barite & As needed & As needed \\
\hline Commercial Fluid loss control agent & 3 & - \\
\hline Amine-treated Quebracho & - & 9 \\
\hline Low shear viscosifier & $0.68 \mathrm{ppb}$ & $0.68 \mathrm{ppb}$ \\
\hline
\end{tabular}

\subsection{Rheological properties}

The rheology of the fluid was characterized in terms of PV, YP and LSYP of the invert emulsion drilling fluid. In this study the YP is obtained from the BinghamPlastic rheological model when extrapolated to a shear rate of zero. The PV represents the viscosity of a fluid when extrapolated to infinite shear rate. Both $\mathrm{PV}$ and $\mathrm{YP}$ are calculated using 300 revolutions per minute (rpm) and 600-rpm shear rate readings on a standard oilfield viscometer as given in Equations 2 and 3. The yield stress is the stress that must be applied to a material to make it begin to flow (or yield), and it is calculated from viscometer dial readings measured at rates of $3,6,100$, 200, 300 and $600 \mathrm{rpm}$. The extrapolation in this case may be performed by applying a curve fit to the Herschel-Bulkley rheological model. The LSYP can be estimated reasonably by Equation 4 . 
$\mathrm{PV}=(600 \mathrm{rpm}$ reading $)-(300 \mathrm{rpm}$ reading $)$

$\mathrm{YP}=(300 \mathrm{rpm}$ reading $)-\mathrm{PV}$

LSYP $=[2 \times(3 \mathrm{rpm}$ reading $)]-(6 \mathrm{rpm}$ reading $)$

The gels formed in the IEF were characterized by the 10- min gel strength, which represents dial reading inflection at 3 rpm on the viscometer, after keeping the IEF static for an interval of $10 \mathrm{~min}$.

Gel strength measurements were performed on a Brookfield viscometer. The procedure uses the Brookfield DV-II Programmable Viscometer to measure gel strengths with a vane spindle. The test allows for a more detailed description of the gel structure and uses much lower revolution speeds than the 12-speed standard oilfield viscometer. In a typically experiment, a 0.5 rpm shear is applied to break the gels formed at defined intervals of 10 and $30 \mathrm{~min}$ [10-13].

\section{Results and Discussion}

Effect of formulation: to demonstrate the effectiveness and compatibility of drilling fluid systems, these drilling fluids were prepared according to standard OBM mixing procedure.

These fluids were hot rolled at $250^{\circ} \mathrm{F}$ for 16 hours. After heat aging, the rheological properties of the test fluids were measured with using a fann 35 rheometer at $120^{\circ} \mathrm{F}$. The HTHP filtration tests were conducted using high-pressure cells at $250^{\circ} \mathrm{F}$ with 500 -psi differential pressure. Figure 1 shows the rheological properties and figure 2 shows the HTHP fluid loss properties of the heat aged fluids.

Temperature Stability of ATQ type of Synthetic-Based Drilling Fluid: Thermal stability of a drilling fluid is considered to be an important aspect of drilling fluid. Most of the drilling fluid formulations are stable in the range of 250 to $300^{\circ} \mathrm{F}$.
However once temperatures exceed $300^{\circ} \mathrm{F}$, then thermal stability of the fluid formulation and additives becomes an issue.

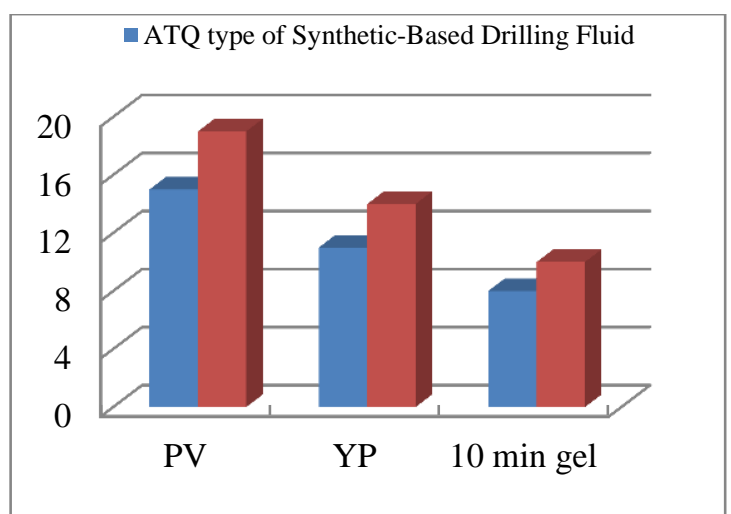

Figure 1. Rheological properties of different type of Synthetic base fluid

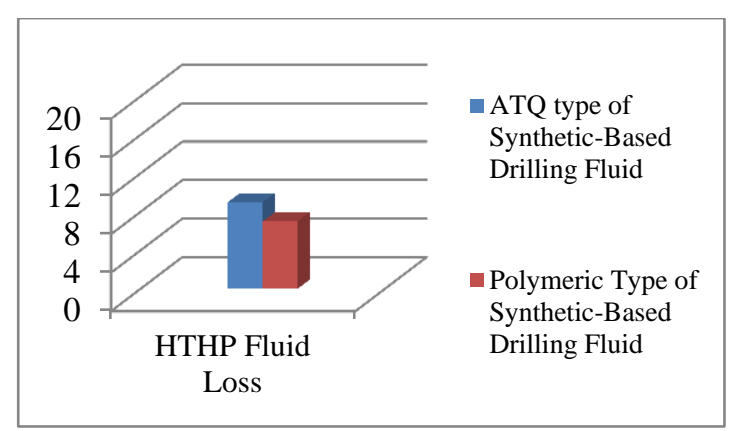

Figure 2. HTHP fluid loss test of different type of Synthetic base fluid

To demonstrate the temperature stability, second fluid formulations with mud weight of $7.6 \mathrm{lb} / \mathrm{gal}$ and $\mathrm{O} / \mathrm{W}$ ratio of 80:20 was utilized. This fluid formulation was heat aged at temperatures ranging from 300 to $400{ }^{\circ} \mathrm{F}$, for 16 hours. After each heat aging cycle, the rheological properties were measured at $120^{\circ} \mathrm{F}$. The HTHP fluid loss was conducted with high pressure cells at $300^{\circ} \mathrm{F}$ with 500 -psi differential pressure.

The results for the $15 \mathrm{lb} / \mathrm{gal}$ mud are given in Figures 3 and 4. Figure 5 gives the rheology and HTHP fluid loss for $16 \mathrm{lb} / \mathrm{gal}$ drilling fluid aged at $375^{\circ} \mathrm{F}$ [14]. 


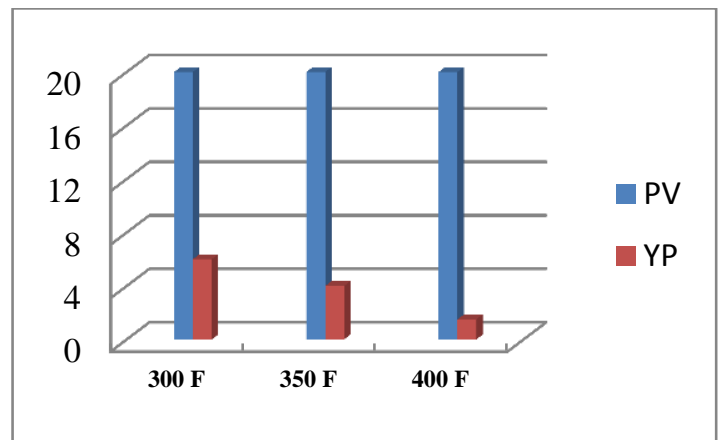

Figure 3. Rheological properties of fluid formulations aged at temperatures from 300 to $400{ }^{\circ} \mathrm{F}$.

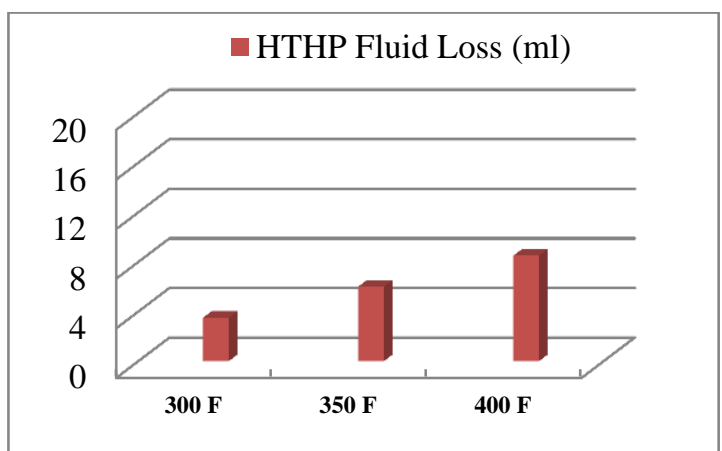

Figure 4. HTHP fluid loss test at $300{ }^{\circ} \mathrm{F}$ with a 500-psi differential

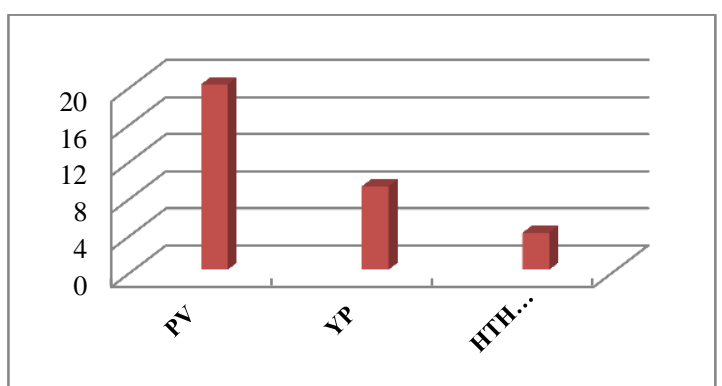

Figure 5. Rheological properties and HTHP fluid loss test at $300^{\circ} \mathrm{F}$

\section{Conclusions}

Two types of synthetic based drilling fluids for high temperature applications has been developed and tested in the laboratory methods. Mud properties such as YP, 6-rpm readings, 10 second and 10 minute gel strengths were measured by API methods.
Amine treated quebracho-based synthetic drilling fluid properties values of PV and YP were satisfactory and of similar values to the desired property values. The emulsion stability for this mud was satisfactory. This product is stable to temperature greater than $500^{\circ} \mathrm{F}$ and performs well in high temperature - high pressure laboratory tests. From the data of evaluation of the new prepared ester utilized in the ester-based mud we can conclude the following:

1-Rheological properties of the Amine treated quebracho-based synthetic drilling fluid showed superior results compared to the usual ester-based mud formulated with Polymeric Agent.

2-The effect of temperature on the rheological properties of new ester-based mud (AQ) formulated with the amine treated quebracho that show a slight decrease with increasing temperature compared to usual ester-based mud formulated with Polymeric Agent, also it is stable at high temperature and pressure with continuous circulation (thermal stability).

3-Gel strength of ester-based muds formulated with the amine treated quebracho showed a gradual decrease by increasing temperature as the usual ester-based mud formulated with Polymeric Agent.

4-Filtration properties of ester-based muds formulated with the amine treated quebracho showed less filter loss compared to the polymeric agent ester-based mud.

\section{Acknowledgements}

The author would like to thank exploration directorate for supporting this Research.

\section{References}

[1] Pereira, M.S., Panisset, C.M.A., Lima, T.B., Ataíde, C.H. (2012) Determination of the chemical and mineralogical 
composition of drilled cuttings at different points throughout the solids control process, Mater. Sci. Forum 727, $1677-1682$.

[2] Darley H.C.H., Gray. G.R. (1988) Composition and Properties of Drilling and Completion Fluids, fifth ed., Butterworth-Heinemann, United States.

[3] Pereira M.S., Ataíde C.H., Naufel R., C.M.A. Panisset, C.H.M. Sa, A.L. Martins. (2013) Microwave Heating: A Feasible Alternative for Drilled Cuttings Drying in Offshore Environments, SPE/IADC Drilling Conference and Exhibition.

[4] Hall, J. (1999) Ester-based drilling fluids: still the best environmental option?

[5] Svon Tapavicza, Hall. J. (2002) Development of environmentally safe drilling fluids based on esters. Presentation at the OFiC 2002. 7-10 October 2002. Kuala Lumpur. (introd).

[6] Samira B.H., M. B, Pet. J. Sci. Eng. (2009) 84-90.

[7] Environmental protection Agency Part III, 40 CFA part 435- Fedral Register 64 (22) (1999) 5488-5554.

[8] Patel, A.D. (1998) Choosing the Right Synthetic-Based Drilling Fluids: Drilling Performance versus Environmental Impact. SPE39508, SPE India Oil \& Gas Conference. New Delhi.

[9] de Boer, L. (2003) Method and apparatus for varying the density in drilling fluids in deep water oil drilling applications, United States Patent 6,536-540.

[10] American Petroleum Institute (1998) Recommended practice, standard procedures for oil field testing, API recommended practice $13 \mathrm{~B}-2$, third ed., 5-11.

[11] Longeron, D., Alfenore J. and PouxGuillaume, G. (1998) Drilling Fluids Filtration and Permeability Impairment: Performance Evaluation of Various Mud
Formulations, SPE 48988. SPE annual Technical Conference. New Orleans. September 27-30.

[12] Beck, F.E. et al. (1995) The Effect of Rheology on Rate of Penetration. SPE/lADC 29368, SPE/lADC,Drilling Conference and Exhibition, Amsterdam, February 28 - March 2.

[13] Patel, A.D. and Salandanan, C.S. (1985) Thermally Stable Polymeric Gellant for Oil-Base Drilling Fluids. SPE 13560, SPE International Symposium on Oilfield and Geothermal Chemistry, Phoenix, April 9-11, 1985.

[14] Lahalih SM, Dairanieh IS (1989) Development of novel polymeric drilling mud dispersants. Eur Polym J., 25:187192. 


\title{
EKSPERIMENTALNO ISPITIVANJE NOVIH ADITIVA ZA OPTIMIZACIJU ISPLAKE NA BAZI SINTETIKE
}

\author{
Ali Akbar Daya, Majid sajjadian, Ehsan Esmaeilpour Motlagh
}

University of Sistan and Baluchestan, Department of Mining Engineering, Zahedan, Iran

(Primljen: 5. Oktobar 2015.; Prihvaćen: 8. Novembar, 2016.)

\begin{abstract}
Izvod
Fokus ovog rada je na dizajnu, razvoju i testiranju dva tipa isplaka na bazi sintetike koje uključuju amino tretirani Quebracho agent i Polymeric Fluid Loss agent. Amino tretirani Quebracho agent je kompatibilan sa drugim hemijskim aditivima u isplakama na bazi sintetike i pokazuje stabilnost na visokim temperaturama, male gubitke fluida i dobre reološke karakteristike. Za optimizaciju parametara bušenja su korišćeni tradicionalne emulzione isplake prevashodno zbog toga što se pri njihovoj upotrebi postižu velike brzine bušenja i dobra stabilnost bušotine. Emulzione isplake zahtevaju primenu različitih aditiva podešavanje i kontrolu emulzije, viskoziteta i gubitaka fluida. Ovaj rad prikazuje laboratorijsku ocenu primene dva aditiva u uslovima visokih temperatura
\end{abstract}

Ključne reči: isplake na bazi sintetike; reološka svojstva; temperaturna stabilnost.

\footnotetext{
${ }^{\#}$ Kontakt adresa autora: aliakbardaya@eng.usb.ac.ir
} 